\title{
New species and records of Palaearctic Campopleginae, Cryptinae, Hybrizontinae, and Tersilochinae (Hymenoptera: Ichneumonidae)
}

\author{
Z. VAS \\ Zoltán Vas, Hungarian Natural History Museum, Department of Zoology, Hymenoptera Collection, H-1088 \\ Budapest, Baross u.13., Hungary.E-mail:vas.zoltan@nhmus.hu
}

\begin{abstract}
The following taxonomical and faunistical results are presented in this paper: regarding Campopleginae, Lathrostizus atrox sp. nov. and Phobocampe kaszabi sp. nov. are described from Mongolia, and the first records of Phobocampe brumatae Horstmann, 2009, Phobocampe pulchella (Thomson, 1887) and Phobocampe quercus Horstmann, 2008 from Hungary, and Clypeoplex cerophagus (Gravenhorst, 1829) from Bulgaria are reported; regarding Cryptinae, Thaumatogelis lichtensteini (Pfankuch, 1913) is first reported from Moldova; regarding Hybrizontinae, the first records of Ghilaromma ussuriensis Tobias, 1988 from North Korea, Hybrizon buccatus (Brebisson, 1825) from Serbia, Kosovo, Romania and North Korea, Hybrizon ghilarovi Tobias, 1988 from Germany, and Hybrizon pilialatus Tobias, 1988 from Romania are reported; regarding Tersilochinae, the first Hungarian records of Probles (Euporizon) truncorum (Holmgren, 1860) and Tersilochus (Tersilochus) obliquus (Thomson, 1889) are given.
\end{abstract}

Keywords. Clypeoplex, Ghilaromma, Hybrizon, Lathrostizus atrox sp. nov., Phobocampe kaszabi sp. nov., Probles, Tersilochus, Thaumatogelis

\section{INTRODUCTION}

$\mathrm{T}_{\mathrm{I}}^{\mathrm{k}}$ he continuing identification process of the Ichneumonidae material in the Hungarian Natural History Museum (HNHM, Budapest) already resulted in several taxonomical and faunistical discoveries regarding the Palaearctic region in the recent years (see e.g. Vas 2013, Vas et al. 2015, Vas 2015, 2016a, b, c, d, e, Vas \& Kutasi 2016, Vas \& Schwarz 2018, Vas 2018, 2019a, b, c, d, $e$ ). The most recent results are presented in this paper as follows. Two new species of Campopleginae, Lathrostizus atrox sp. nov. and Phobocampe kaszabi sp. nov. are described from Mongolia, and 11 species of subfamilies Campopleginae, Cryptinae, Hybrizontinae and Tersilochinae are first reported from eight countries of the Palaearctic region.

\section{MATERIAL AND METHODS}

Taxonomy and nomenclature follow $\mathrm{Yu} \&$ Horstmann (1997), and Yu et al. (2012); hence, complete nomenclatural history and list of syno- nym taxa are not repeated here. The applied morphological terminology is primarily based on Gauld (1991) and Gauld et al. (1997); however, in some cases, especially about of wing veins, the corresponding terminology of Townes (1969) is also given. Identifications were based on Uchida (1954), Horstmann (1971 a, b, 1978, 1981), Kasparyan (1981), Gupta (1983), Kusigemati (1988, 1993), Xu \& Sheng (1994), He et al. (1996), Achterberg (1999), Jonathan (1999), Schwarz (2001), Horstmann (2004), Šedivý (2004), Khalaim \& Kasparyan (2007), Horstmann (2007, 2008, 2009), Khalaim \& Yurtcan (2011), Choi et al. (2012), Konishi et al. (2012), Achterberg et al. (2013), Vas \& Schwarz (2018), Liu et al. (2019), and on checking the relevant type materials. Distributional records of species were primarily checked and traced through the database of $\mathrm{Yu}$ et al. (2012). The specimens were identified and examined by the author using a Nikon SMZ645 stereoscopic microscope, and are deposited in the Hymenoptera Collection of HNHM. Photos were taken with Nikon D5200 and Nikon AF Micro Nikkor 60mm lens and MitutoyoM Plan Apo 5X 
microscope lens. Exposures were stacked in ZereneStacker 1.04, post image work was done with ImageJ $1.52 \mathrm{c}$ and Photoshop CS5.

\section{RESULTS}

\section{Taxonomy}

\section{Campopleginae Förster, 1869}

\section{Lathrostizus Förster, 1869}

Type species. Lathrostiza stenocera Thomson, 1887; designation by Viereck (1914).

\section{Lathrostizus atrox sp. nov.}

(Figures 1-2)

Material examined. Holotype: female, Mongolia, Central aimak, Ulan-Baator, Nucht im Bogdo ul, 1880-2000m, 9.VI.1966, leg. Z. Kaszab (Nr. 508); specimen card-mounted; Id. No. HNHMHYM 153173. - The holotype is deposited in the Hymenoptera Collection of HNHM (Budapest, Hungary).

Diagnosis. The new species can be distinguished from all known Lathrostizus species by the following characters in combination: posterior transverse carina of mesosternum strong, distinctly elevated, not forming backward projecting lobe, submedially slightly convex, medially shallowly indented; area superomedia little longer than wide, its lateral sides arched, divergent above and convergent below the level of costulae; ovipositor sheath $1.25 \times$ as long as first tergite, ovipositor distinctly upcurved in apical third, slightly upcurved in basal two-third; all legs with coxae, trochanters, trochantelli black, femora almost entirely black, apically narrowly ferruginous, tibiae entirely ferruginous, tarsi ferruginous, apically brownish. The new species is somewhat similar to the Western Palaearctic species Lathrostizus alpinus Horstmann, 1971, which can easily be distinguished from the new species by its basally ivory, subbasally and apically blackish hind tibia.
Description. Female (Figs. 1-2). Body length ca $5.5 \mathrm{~mm}$, fore wing length $c a 4 \mathrm{~mm}$.

Head. Antenna with 25 flagellomeres; first flagellomere $c a 2.5 \times$ as long as its apical width; preapical flagellomeres slightly longer than wide. Head transverse, granulate, and with relatively short, dense greyish hairs. Ocelli small, ocularocellar distance $1.4 \times$ as long as ocellus diameter, posterior ocellar distance $c a 2.5 \times$ as long as ocellus diameter. Inner eye orbits slightly indented, parallel. Gena (temple) long, swollen, in dorsal view about as long as eye width, subparallel then slightly narrowed behind eye; gena in lateral view wider than eye width along ventral half of eye length, ventrally weakly narrowed and concave. Occipital carina complete, ventrally weakened, reaching hypostomal carina distinctly before mandibular base; hypostomal carina slightly elevated. Malar space $c a 0.75 \times$ as long as basal width of mandible. Face and clypeus almost flat in profile, weakly separated; maximum face width about as wide as frons below middle ocellus. Clypeus wide, granulate with few indistinct, superficial punctures, its apical margin truncate, sharp. Mandible relatively long, lower margin of mandible with wide carina from teeth toward base, mandibular teeth about equal.

Mesosoma. Mesosoma granulate to coarsely granulate with weak, superficial, indistinct punctures, and with short, greyish hairs, hairs denser on dorsal parts than on lateral parts, and longer on propodeum. Pronotum with relatively strong, irregular wrinkles on lower two-third; epomia distinct. Mesoscutum convex in profile, about as long as wide; notaulus not developed. Scutoscutellar groove deep and wide, almost smooth within. Scutellum strongly convex in profile, without lateral carina. Mesopleuron coarsely granulate with irregular wrinkles anterodorsal to speculum and along anterior margin; speculum mostly granulate, ventrally a small spot very finely granulate to almost smooth; mesopleural suture with short transverse costae. Pleural and ventral part of epicnemial carina complete, strong; transverse part (i.e. part at the level of sternaulus running through the epicnemium to the ventral edge of pronotum) absent; pleural part obliquely 


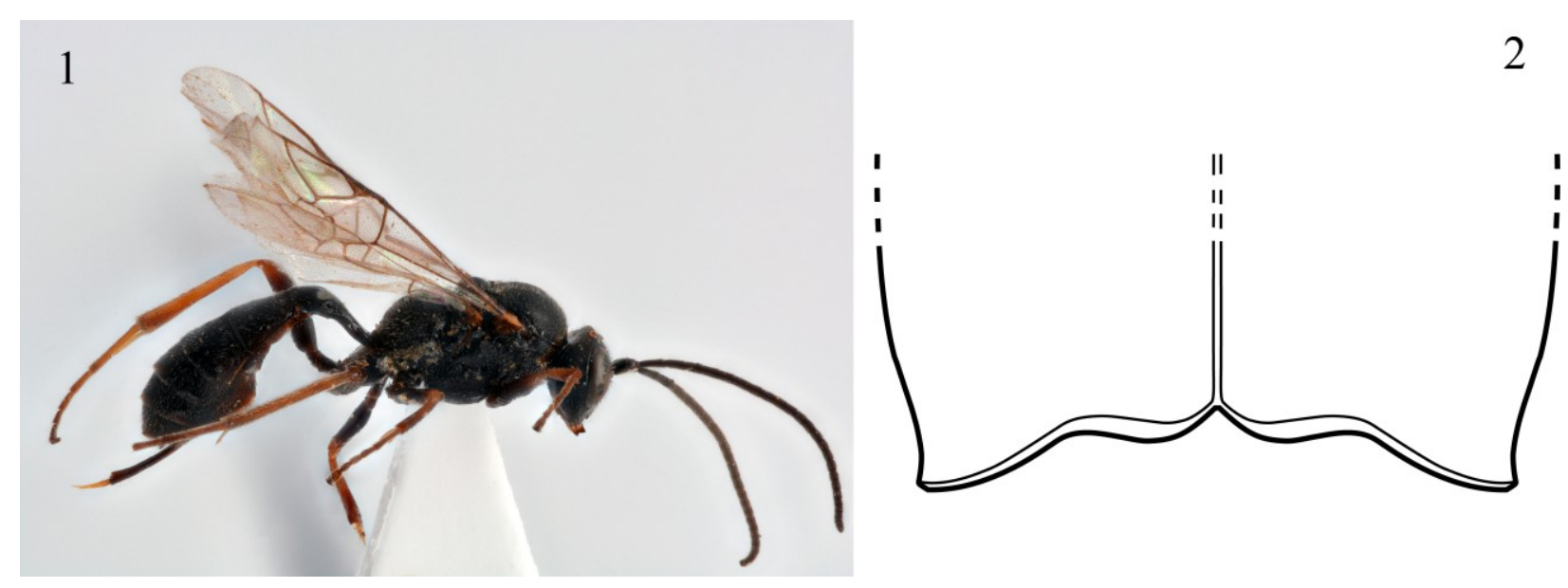

Figures 1-2. Holotype of Lathrostizus atrox sp. nov., female. 1 = lateral habitus; 2 = posterior transverse carina of mesosternum (posterior half of mesosternum in ventral view is depicted, head upward).

bent to anterior margin of mesopleuron reaching it below its middle height, ventral part slightly elevated. Sternaulus indistinct. Posterior transverse carina of mesosternum complete, strong, distinctly elevated, not forming backward projecting lobe, submedially slightly convex, medially shallowly indented. Metanotum finely granulate, about $0.5 \times$ as long as scutellum. Metapleuron granulate; juxtacoxal carina absent; submetapleural carina complete. Pleural carina of propodeum complete; propodeal spiracle small, subcircular, separated from pleural carina by about $2 \times$ its greatest diameter, spiracle connected to pleural carina by a weak ridge. Propodeum coarsely granulate to rugose, with distinct transverse wrinkles; propodeal carinae relatively weak except basal parts of lateromedian longitudinal carinae. Costula (section of anterior transverse carina between lateromedian and lateral longitudinal carinae) present but weak, especially distally, and connected to lateral margin of area superomedia slightly behind its middle. Area basalis very small and short, trapezoidal, about half as long as its basal width. Area superomedia about $1.2 \times$ as long as its greatest width, its lateral sides arched, rather divergent above the level of costulae, little convergent below the level of costulae; area superomedia apically opened, confluent with area petiolaris, both areas densely covered with transverse wrinkles. Fore wing with long-stalked, rather small areolet, second recurrent vein $(2 m-c u)$ dis- tinctly distal to its middle, $3 r s-m$ pigmented; distal abscissa of $R s$ straight, its distal fourth slightly bent toward anterior wing margin; distal half of distal abscissa of $M$ weakly pigmented; nervulus $(c u-a)$ postfurcal by about its width, slightly inclivous; postnervulus (abscissa of $\mathrm{Cu} 1$ between $1 m-c u$ and $C u 1 \mathrm{a}+C u 1 \mathrm{~b}$ ) intercepted little below its middle by $C u 1 \mathrm{a}$; lower external angle of second discal cell about right-angled. Hind wing with nervellus ( $c u-a+$ abscissa of $C u 1$ between $M$ and $\mathrm{Cu}-a$ ) about vertical, not intercepted; discoidella (distal abscissa of $C u 1$ ) not connected to nervellus, spectral. Coxae finely granulate. Hind femur relatively stout, ca $4 \times$ as long as high. Inner spur of hind tibia distinctly longer than outer spur, inner spur ca $0.6 \times$ as long as hind basitarsus. Hind basitarsus without a midventral row of closely spaced, short hairs. Tarsal claws small, slightly shorter than arolium, with few weak basal pecten.

Metasoma. Metasoma moderately compressed, granulate to coriaceous, with weak, hardly discernible punctures on apical tergites and epipleura, and with moderately dense, greyish hairs. First tergite $c a 2.3 \times$ as long as its apical width; glymma relatively small, shallow; dorsomedian carina of first tergite very weak, hardly discernible. Second tergite about $0.9 \times$ as long as its apical width; thyridium relatively small, oval, its distance from basal margin of tergite slightly longer than its length. Epipleurum of second and third tergites separated by a crease. Third and following tergites 
wider than long, posterior margins medially not excised. Ovipositor sheath $1.25 \times$ as long as first tergite, in lateral view parallel-sided, medially not widened, ovipositor weakly upcurved in basal two-third, distinctly upcurved in apical third, dorsal preapical part shallowly concave without distinct teeth, tip acute.

Colour. Antenna black. Head black except palpi and mandibles medially reddish brown, mandibular teeth brown. Mesosoma black, tegula blackish to dark brownish. Metasoma black, posterior margins of apical tergites narrowly, rather indistinctly reddish-brown. Wings hyaline, wing veins brown, pterostigma brownish, along its anterior margin dark brown. Legs: coxae, trochanters, trochantelli black; femora almost entirely black, apically narrowly ferruginous (rustcoloured); tibiae entirely ferruginous; tarsi ferruginous, apical tarsomeres brownish.

Male. Unknown.

\section{Distribution. Mongolia.}

Etymology. The specific epithet is the feminine form of the Latin adjective atrox meaning frightening, fierce, heinous; it refers to the dark, dreadful general habitus of the new species.

Remarks on identification. By using the identification key published by Horstmann (2004), Lathrostizus atrox sp. nov. might key out with Lathrostizus alpinus at couplet 12, however, it already fails to show complete match to the second half of couplet 10 regarding colouration of hind tibia. The distinctive characteristics from Lathrostizus alpinus are given in the Diagnosis section.

\section{Phobocampe Förster, 1869}

Type species. Campoplex crassiusculus Gravenhorst, 1829; designation by Viereck (1914).

\section{Phobocampe kaszabi sp. nov.}

(Figures 3-5)

Material examined. Holotype: female, Mongolia, Čojbalsan aimak, 20 km SW v. Somon Bajan- uul, 820m, 18.VIII.1965, leg. Z. Kaszab (Nr. 444); specimen card-mounted; Id. No. HNHMHYM 153174. - The holotype is deposited in the Hymenoptera Collection of HNHM (Budapest, Hungary).

Diagnosis. The new species can be distinguished from all known Phobocampe species by the following characters in combination: gena short, strongly narrowed behind eyes; malar space $0.3-0.4 \times$ as long as basal width of mandible; mesosoma, including speculum, entirely granulate without discernible punctures; area superomedia at the level of costulae $2 \times$ as wide as its length above the level of costulae; lateromedian longitudinal carinae behind costulae shortly convergent then widely divergent; area superomedia and area petiolaris granulate without distinct wrinkles; propodeal spiracle short oval, separated from pleural carina by $1.2 \times$ its greatest diameter; posterior transverse carina of mesosternum weakened, almost interrupted before middle coxae, laterally and medially present, medially rather strongly excised; glymma small, very shallow; first tergite with distinct dorsomedian carina over its entire length; postpetiolus wider than long in dorsal view; second tergite $0.95 \times$ as long as its apical width; ovipositor sheath shorter than apical depth of metasoma; areolet small, petiolate; lower external angle of second discal cell almost rightangled; hind coxa entirely reddish; hind femur reddish, apically narrowly darkened; hind tibia basally and apically relatively narrowly dark brownish, externo-medially ivory, interno-medially reddish; metasoma blackish except second tergite dark brownish with reddish band on apical half and third tergite dark brownish with reddish brown lateral patches. Phobocampe kaszabi sp. nov. is most similar to the Western Palaearctic species Phobocampe pulchella (Thomson, 1887), which differs from the new species by the following caracters: area superomedia wider (at the level of costulae about $2.5 \times$ as wide as its length above the level of costulae) and behind costulae distinctly longer with parallel or subparallel lateral carinae; area superomedia apically and area petiolaris with weak but distinct wrinkles; propodeal spiracle oval, separated from pleural carina 


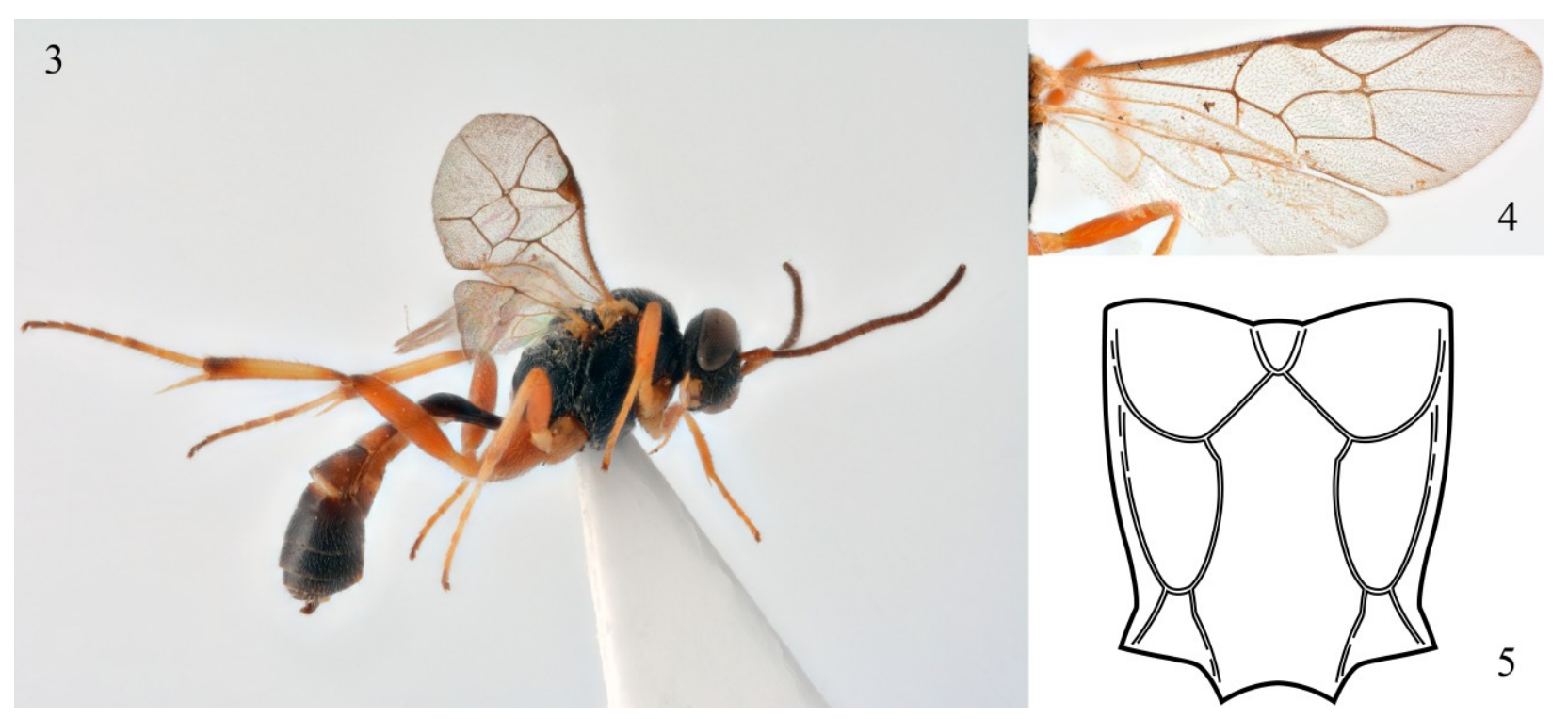

Figures 3-5. Holotype of Phobocampe kaszabi sp. nov., female. $3=$ lateral habitus; 4 = wings, dorsal view; $5=$ propodeal carination, dorsal view (only carinae are depicted, other surface structures not).

by distinctly less than its greatest diameter; posterior transverse carina of mesosternum complete and slightly elevated along entire length, medially only slightly excised; lower external angle of second discal cell distinctly acute; speculum ventrally more or less shinier, subpolished; third tergite brown to reddish brown without distinct lateral reddish patches.

Description. Female (Figs 3-5). Body length ca $5 \mathrm{~mm}$, fore wing length ca $4 \mathrm{~mm}$.

Head. Antenna with 25 flagellomeres; first flagellomere slender, $\mathrm{ca} 3 \times$ as long as its apical width; preapical flagellomeres little longer than wide. Head transverse, granulate, and with relatively long whitish hairs. Ocular-ocellar distance slightly shorter than ocellus diameter, posterior ocellar distance $c a 1.5 \times$ as long as ocellus diameter. Inner eye orbits slightly indented, ventrally weakly convergent. Gena (temple) more finely granulate than other parts of head with scattered, very weak, indistinct punctures, short, strongly narrowed behind eye, in dorsal view about $0.35 \times$ as long as eye width. Occipital carina complete, reaching hypostomal carina little before mandibular base; hypostomal carina not elevated. Malar space short, $0.3-0.4 \times$ as long as basal width of mandible. Face and clypeus flat in profile, mode- rately coarsely granulate, matt, maximum face width about $0.8 \times$ as wide as frons below middle ocellus. Clypeus weakly separated from face, with weak subapical groove, apical margin sharp, shiny, very weakly convex, medially truncate. Lower margin of mandible with wide flange from teeth toward base, upper mandibular tooth slightly longer and higher than lower tooth.

Mesosoma. Mesosoma granulate without discernible punctures, and with short, whitish-greyish hairs, hairs denser on dorsal parts than on lateral parts. Pronotum with relatively weak wrinkles on lower half; epomia distinct. Mesoscutum moderately coarsely granulate, convex in profile, slightly wider than long; notaulus not developed. Scutellum convex in profile, without lateral carina. Mesopleuron, including speculum, granulate, with a few, indistinct diagonal wrinkles anterodorsal to speculum; mesopleuron posteromedially, below speculum, impressed; mesopleural suture rather deep with strong, short transverse costae. Pleural and ventral part of epicnemial carina complete, strong, not elevated; transverse part (i.e. part at the level of sternaulus running through the epicnemium to the ventral edge of pronotum) absent; pleural part obliquely bent to anterior margin of mesopleuron reaching it below its middle height. Sternaulus indistinct. 
Posterior transverse carina of mesosternum weakened, almost interrupted before each middle coxae, laterally and medially present, slightly elevated, medially rather strongly excised. Metanotum finely granulate, short, about $0.4 \times$ as long as scutellum. Metapleuron granulate; juxtacoxal carina absent; submetapleural carina complete. Pleural carina of propodeum strong; propodeal spiracle short oval, separated from pleural carina by $1.2 \times$ its greatest diameter, spiracle connected to pleural carina by a distinct ridge. Propodeum short, entirely granulate without distinct wrinkles; propodeal carinae distinct. Costula (section of anterior transverse carina between lateromedian and lateral longitudinal carinae) strong, complete, connecting to lateral margin of area superomedia behind its middle. Lateromedian longitudinal carinae behind costulae shortly convergent, this convergent part slightly weaker than other parts of carinae, then widely divergent, then at extreme apex convergent. Area basalis triangular, longer than its basal width, its lateral carinae weak. Area superomedia basally triangular, wide, at the level of costulae $2 \times$ as wide as its length above the level of costulae; area superomedia below costulae shortly constricted, apically opened, confluent with area petiolaris. Fore wing with small, petiolate areolet, second recurrent vein $(2 m-c u)$ distinctly distal to its middle, $3 r s-m$ pigmented; distal abscissa of $R s$ straight; distal half of distal abscissa of $M$ weakly pigmented; anterior half of second recurrent vein $(2 m-c u)$ slightly bent inward; nervulus $(\mathrm{cu}-a)$ postfurcal by about $0.35 \times$ its length, inclivous; postnervulus (abscissa of $\mathrm{Cu} 1$ between $1 m-c u$ and $C u 1 \mathrm{a}+\mathrm{Cu} 1 \mathrm{~b}$ ) intercepted slightly below its middle by $\mathrm{Cu} 1 \mathrm{a}$; lower external angle of second discal cell almost right-angled $\left(\mathrm{ca} 86^{\circ}\right)$. Hind wing with nervellus $(\mathrm{cu}-a+\mathrm{ab}-$ scissa of $C u 1$ between $M$ and $c u$ - $a$ ) weakly inclivous, not intercepted; discoidella (distal abscissa of $\mathrm{Cu1}$ ) not connected to nervellus, spectral. Coxae finely granulate. Hind femur relatively stout, ca $4 \times$ as long as high. Inner spur of hind tibia distinctly longer than outer spur, inner spur $c a$ $0.65 \times$ as long as hind basitarsus. Hind basitarsus without a midventral row of closely spaced, short hairs. Tarsal claws small, slightly shorter than arolium, with few weak, indistinct basal pecten.
Metasoma. Metasoma finely granulate to coriaceous, with dense, whitish-greyish hairs. First tergite relatively stout, $c a 2.2 \times$ as long as its apical width, in dorsal view distinctly widened from basal third toward apex, in lateral view its convex, swollen apical part distinctly longer than flat basal part; glymma small and very shallow; first tergite with distinct dorsomedian carina over its entire length; postpetiolus wider than long in dorsal view (length measured from spiracle to apical margin), its lateral sides convex. Second tergite about $0.95 \times$ as long as its apical width; thyridium large, oval, its distance from basal margin of tergite slightly less than its length. Epipleurum of second and third tergites separated by a crease. Third and following tergites wider than long, posterior margins medially not excised. Ovipositor short, its sheath shorter than apical depth of metasoma, in lateral view apically widened.

Colour. Antenna dorsally brown, ventrally light brown, scapus and pedicellus ventrally yellowish to yellowish brown. Head black except yellowish palpi and mandibles, mandibular teeth reddish brown. Mesosoma black except pale yellow tegula. Metasoma: first tergite blackish to dark brownish, apical margin very narrowly, indistinctly paler; second tergite dark brownish with pale reddish band on apical half; third tergite dark brownish with pale reddish brown lateral patches; fourth and following tergites blackish; ovipositor sheath brown. Wings hyaline, wing veins and pterostigma brown. Fore and middle legs: coxae reddish yellow; trochanters and trochantelli pale yellowish; femora reddish yellow; tibiae reddish yellow, externo-medially pale yellowish; tarsi yellowish, apical tarsomeres brownish. Hind leg: coxa entirely reddish; trochanter and trochantellus pale yellowish; hind femur reddish, apically narrowly darkened; hind tibia externo-medially ivory, interno-medially reddish, its basal 0.15 and apical 0.2 brownish; tarsus brownish, basal 0.7 of basitarsus yellowish.

Male. Unknown.

Distribution. Mongolia.

Etymology. This species is dedicated to the memory of Dr. Zoltán Kaszab (1915-1986), 
former curator of Coleoptera Collection and general director of Hungarian Natural History Museum (Budapest), in honour of his remarkable collecting activity during his one-man collecting trips in Mongolia between 1963-1968.

Remarks on identification. By using the identification key of the revision of Western Palaearctic Phobocampe species (Šedivý 2004), Phobocampe kaszabi sp. nov. might key out with Phobocampe pulchella (Thomson, 1887) or, given that the efficient use of that key requires some experience, either with Phobocampe crassiuscula (Gravenhorst, 1829) or with Phobocampe unicincta (Gravenhorst, 1829). The distinctive characteristics from the most similar species, Phobocampe pulchella, are given in the Diagnosis section. Both other species can be readily distinguished from the new species as follows: Phobocampe crassiuscula by its dark hind coxa, and Phobocampe unicincta by its elongated (usually longer than wide or rarely quadratic) postpetiolus and wider area superomedia (at the level of costulae about $2.5-3 \times$ as wide as its length above the level of costulae).

\section{Faunistics}

\section{Campopleginae Förster, 1869}

\section{Clypeoplex cerophagus (Gravenhorst, 1829)}

Material. Bulgaria, Sofia, Vitosha Mts., 1000 m, 3.VIII.1982, leg. Á. Draskovits \& Á. Vály, 1 q.

Remarks. First record for Bulgaria. This species is widely distributed in the Palaearctic region (Yu et al. 2012).

\section{Phobocampe brumatae Horstmann, 2009}

Material. Hungary, Veszprém County, Szigliget, 20-22.IV.2019, leg. Z. Vas, 10 .

Remarks. First record for Hungary. This species has been known from France and the United Kingdom so far (Horstmann 2009, Yu et al. 2012).

\section{Phobocampe pulchella (Thomson, 1887)}

Material. Hungary, Pest County, Páty, Mézeshegy, 17-25.VI.2018, leg. Z. Vas, 1 ㅇ.

Remarks. First record for Hungary. This species is known from several European countries (Horstmann 2008, Yu et al. 2012).

\section{Phobocampe quercus Horstmann, 2008}

Material. Hungary, Pest County, Törökbálint, collected at 13.V.2019 as cocoon, adult wasp emerged at 6.VI.2019, leg. S. Nagy, 1 ㅇ.

Remarks. First record for Hungary. This species has been known from Germany, Poland, Spain and United Kingdom so far (Horstmann 2008, Yu et al. 2012).

\section{Cryptinae Förster, 1869}

\section{Thaumatogelis lichtensteini (Pfankuch, 1913)}

Material. Moldova, Rîşcani District, Văratic, 9.VII.2018, leg. A. I. Csathó, 1 ㅇ․

Remarks. First record for Moldova. This species is widely distributed in the Western Palaearctic region (Schwarz 2001, Yu et al. 2012, Vas \& Schwarz 2018).

\section{Hybrizontinae Förster, 1869}

\section{Ghilaromma ussuriensis Tobias, 1988}

Material. North Korea [on label: Korea], Ryang-gang Province, Hyesan, Mt. Ze-dong, 1150m, 26.VII.1975, leg. J. Papp \& A. Vojnits, $4 \widehat{○}$.

Remarks. First record for North Korea. This species has been known from East Russia (Primorsky-Krai) (Yu et al. 2012, Konishi et al. 2012).

\section{Hybrizon buccatus (Brebisson, 1825)}

Material. Serbia, Petrovaradin [on label: Pétervárad], 6.VII.1892, leg. unknown, 1․ - Kosovo, 
Peć [on label: İpek], 27.VI.1917, leg. E. Csiki, 1․ - Romania, Cluj County, Ocna Dejului [on label: Désakna], date unknow, leg. E. Zilahi-Kiss, 3+; Bistrița-Năsăud County, Coldău [on label: Kudu], date unknow, leg. E. Zilahi-Kiss, 1क; Mureș County, Socata [on label: Szováta], date unknow, leg. E. Csiki, 3ㅇ; Sălaj County, Cehu Silvaniei [on label: Szilágycseh], date unknow, leg. E. Zilahi-Kiss, 1 9 ; Satu Mare County, Hodod [on label: Hadad], 1904, leg. E. Zilahi-Kiss, 1; Cluj County, Comuna Chiuieşti [on label: Pecsétszeg], VIII.1911, leg. unknown, 1q; Satu Mare County, Tăşnad [on label: Tasnád], VII. 1912, leg. L. Bíró, 1; Alba County, Aiud [on label: Nagyenyed], 20.VIII.1918, leg. Z. Szilády, 1; Harghita County, Odorheiu Secuiesc [on label: Székelyudvarhely], 19.IX.1919, leg. Z. Szilády, 1; A Arad County, Ineu [on label: Borosjenő], 31.V.1922, leg. Diószeghy, 1․ North Korea [on label: Korea], Ryang-gang Province, Plateau Chann-Pay Sam-zi-yan, 1600m, 25-28.VIII.1971, leg. S. Horvatovich \& J. Papp, 4우 Pyongyan, VIII-IX.1971, leg. S. Horvatovich \& J. Papp, 10 ㅇ.

Remarks. First records for Serbia, Kosovo, Romania and North Korea. This species is widely distributed in the Palaearctic region ( $\mathrm{Yu}$ et al. 2012).

\section{Hybrizon ghilarovi Tobias, 1988}

Material. Germany, Dubrow, 7.VII.1965, leg. J. Oehlke, $1{ }^{\lambda}$.

Remarks. First record for Germany. This species has been known from Bulgaria, China, and Far East Russia (Yu et al. 2012, Konishi et al. 2012, Achterberg et al. 2013).

\section{Hybrizon pilialatus Tobias, 1988}

Material. Romania, Sălaj County, Crasna, 14.IX.1982, leg. Andriescu, $4 \bigcirc$.

Remarks. First record for Romania. This Western Palaearctic species has been reported from Austria, Bulgaria, Czech Republic, Germany, Hungary, Italy, Poland and Russia (Kostroma
Oblast) so far (Achterberg 1999, Yu et al. 2012, Mandl 2017, Vas \& Bakardzsiev 2019).

\section{Subfamily: Tersilochinae Förster, 1869}

\section{Probles (Euporizon) truncorum (Holmgren, 1860)}

Material. Hungary, Pest County, Dömsöd, 78.VI.2019, leg. L. Ronkay, M. Ronkayné Tóth \& Z. Vas, at light, 1 .

Remarks. First record for Hungary. This species is widely distributed in the Western Palaearctic region (Yu et al. 2012).

\section{Tersilochus (Tersilochus) obliquus (Thomson, 1889)}

Material. Hungary, Fejér County, Bicske, 20.IV.2019, leg. K. Bakardzsiev, 1 ․

Remarks. First record for Hungary. This species has been known from several European countries so far ( $\mathrm{Yu}$ et al. 2012).

Acknowledgements - I am grateful to Rune Bygebjerg (Biological Museum, Lund) for his help in checking relevant type material, and to Roman Figura (Charles University, Prague) for his help in obtaining relevant literature. I thank the organizers of the annual Biodiversity Days of the Hungarian Biodiversity Research Society as Probles (Euporizon) truncorum (Holmgren, 1860) was collected during this occasion. I thank Tamás Németh (HNHM, Budapest) for the photos. The author was supported by the Hungarian Government, Ministry of Human Capacities (Emberi Erőforrások Minisztériuma) in the frame of the NTP-NFTÖ-19-B-0007 scholarship (Nemzet Fiatal Tehetségeiért Ösztöndij).

\section{REFERENCES}

ACHTERBERG, C. VAN (1999): The West Palaearctic species of the subfamily Paxylommatinae (Hymenoptera: Ichneumonidae), with special reference to the genus Hybrizon Fallén. Zoologische Mededelingen Leiden, 73(2): 11-26.

AchterberG, C. VAN, You, L.S. \& LI, X.Y. (2013): Hybrizon Fallén (Hymenoptera, Ichneumonidae, Hybrizoninae) found in Hunan (China). Journal of Hymenoptera Research, 30: 65-74. doi: $\underline{10.3897 / J H R .30 .3182}$ 
CHOI, J.-K., JEONG, J.-C. \& LEE, J.-W. (2012): Three species of the subfamily Campopleginae (Hymenoptera: Ichneumonidae) new to Korea. Entomological Research, 42: 79-84. doi: $10.1111 / \mathrm{j} .1748-5967.2011 .00362 . \mathrm{x}$

GAULD, I.D. (1991): The Ichneumonidae of Costa Rica, 1. Introduction, keys to subfamilies, and keys to the species of the lower Pimpliform subfamilies Rhyssinae, Poemeniinae, Acaenitinae and Cylloceriinae. Memoirs of the American Entomological Institute, 47: 1-589.

GAUld, I.D., Wahl, D., BRADShaw, K., Hanson, P. \& WARD, S. (1997): The Ichneumonidae of Costa Rica, 2. Introduction and keys to species of the smaller subfamilies, Anomaloninae, Ctenopelmatinae, Diplazontinae, Lycorininae, Phrudinae, Tryphoninae (excluding Netelia) and Xoridinae, with an appendix on the Rhyssinae. Memoirs of the American Entomological Institute, 57: 1-485.

GUPTA, V.K. (1983): The Ichneumonid parasites associated with the gypsy moth (Lymantria dispar). Contributions to the American Entomological Institute, 19(7): 1-168.

HE, J.H., CHEN, X.X. \& MA, Y. (1996): Hymenoptera: Ichneumonidae. Economic Insect Fauna of China. Science Press, Beijing, 697 pp.

HORSTMANN, K. (1971a): Revision der europäischen Arten der Gattung Lathrostizus Förster (Hymenoptera, Ichneumonidae). Mitteilungen der Deutschen Entomologischen Gesellschaft, 30: 8-12, 16-18.

HORSTMANN, K. (1971b): Revision der europäischen Tersilochinen I (Hymenoptera, Ichneumonidae). Veröffentlichungen der Zoologischen Staatssammlung (München), 15: 47-138.

HorstmanN, K. (1978): Bemerkungen zur Systematik einiger Gattungen der Campopleginae II. Mitteilungen Münchener Entomologischen Gesellschaft, 67(1977): 65-83.

HORSTMANN, K. (1981): Revision der europäischen Tersilochinen II (Hymenoptera, Ichneumonidae). Spixiana, Suppl. 4(1980): 1-76.

HorstmanN, K. (2004): Bemerkungen zur Systematik einiger Gattungen der Campopleginae IV (Hymenoptera, Ichneumonidae). Zeitschrift der Arbeitsgemeinschaft Österreichischer Entomologen, 56: 13-35.

HORSTMANN, K. (2007): Revisionen von Schlupfwespen-Arten XI (Hymenoptera: Ichneumonidae).
Mitteilungen Münchener Entomologischen Gesellschaft, 97: 73-80.

HORSTMANN, K. (2008): Neue westpaläarktische Arten der Campopleginae (Hymenoptera: Ichneumonidae). Zeitschrift der Arbeitsgemeinschaft Österreichischer Entomologen, 60(1-2): 3-27.

HORSTMANN, K. (2009): Revisionen von Schlupfwespen-Arten XIII (Hymenoptera: Ichneumonidae). Mitteilungen Münchener Entomologischen Gesellschaft, 99: 37-44.

JONATHAN, J.K. (1999): Hymenoptera: Ichneumonidae. Fauna of West Bengal. Part. 8. Insecta (Trichoptera, Thysanoptera, Neuroptera, Hymenoptera and Anoplura). Zoological Survey of India, Calcutta, pp. 442.

KASPARYAN, D.R. (1981): A guide to the insects of the European part of the USSR. Hymenoptera, Ichneumonidae. 11 Ctenopelmatinae. 12 Phrudinae. 13 Tersilochinae. 14 Cremastinae. 15 Campopleginae. 16 Ophioninae. Opredeliteli Fauny SSSR, 3(3): 316-431.

KHALAIM, A.I. \& KASPARYAN, D.R. (2007): Subfamily Campopleginae. In: LELEJ, A.S. (ed.) Key to the insects of Russia Far East. Vol. IV. Neuropteroidea, Mecoptera, Hymenoptera. Pt 5. Dalnauka, Vladivostok, pp. 597-632.

Khalaim, A.I. \& Yurtcan, M. (2011): A survey on Tersilochinae (Hymenoptera: Ichneumonidae) species of Turkey, with a key to European genera. Turkish Journal of Zoology, 35(3): 381-394.

Konishi, K., CHOI, M.-B. \& LEE, J.-W. (2012): Review of the East Asian species of the genera Hybrizon Fallén and Ghilaromma Tobias (Hymenoptera: Ichneumonidae: Hybrizontinae). Entomological Research, 42: 19-27. doi: 10.1111/j.1748-5967.2011.00352.x

KUSIGEMATI, K. (1988): New host records of Ichneumonidae (Hymenoptera) with descriptions of two new species from Japan (VI). Kontyu, 56: 573-580.

Kusigemati, K. (1993): Descriptions of three new Ichneumonflies (Hymenoptera) parasitic on economic hosts from Japan. Japanese Journal of Entomology, 61: 235-242.

LiU, J.-X., ACHTERBERG, C. VAN, ZHENG, B.-Y. \& YANG, Q.-M. (2019): Hybrizon Fallén (Hymenoptera, Ichneumonidae, Hybrizontinae) in China. Journal of Hymenoptera Research, 72: 11-26. doi: $\underline{10.3897 / \mathrm{jhr} .72 .39333}$ 
MADL, M. (2017): Erstnachweis von Hybrizon pilialatus Tobias, 1988 (Hymenoptera: Ichneumonidae: Hybrizontinae) in Österreich. Beiträge zur Entomofaunistik, 18: 151.

SCHWARZ, M. (2001): Revision der westpaläarktischen Arten der Gattungen Gelis Thunberg mit apteren Weibchen und Thaumatogelis Schwarz (Hymenoptera, Ichneumonidae). Teil 4. Linzer Biologische Beiträge, 33(2): 1111-1155.

ŠEDIVÝ, J. (2004): European species of the genus Phobocampe Förster (Hymenoptera: Ichneumonidae). Acta Universitatis Carolinae Biologica, 48: 203-235.

TOWNES, H. (1969): The genera of Ichneumonidae. Part 1. Memoirs of the American Entomological Institute, 11: 1-300.

UCHIDA, T. (1954): Ein neuer Schmarotzer des japanischen Ringelspinners (Hymenoptera, Ichneumonidae, Cryptinae). Mushi, 26: 17-18.

VAS, Z. \& BAKARDZSIEV, K. (2019): Hybrizontinae of Hungary (Hymenoptera: Ichneumonidae). Folia entomologica hungarica, 80: in press

VAS, Z. \& KUTASI, CS. (2016): Hymenoptera from caves of Bakony Mountains, Hungary - an overlooked taxon in hypogean research. Subterranean Biology, 19: 31-39.

doi: $\underline{10.3897 / \text { subtbiol.19.10016 }}$

VAS, Z. \& SCHWARZ, M. (2018): Contributions to the taxonomy, identification, and biogeography of Thaumatogelis Schwarz, 1995 (Hymenoptera: Ichneumonidae). Zootaxa, 4444(4): 421-436. doi: 10.11646/zootaxa.4444.4.4

VAS, Z. (2013): First records of three ichneumon wasp species in Hungary (Hymenoptera: Ichneumonidae). Folia entomologica hungarica, 74: 189-194.

VAS, Z. (2015): New records of ichneumon wasps in Hungary, Romania, Serbia and Slovakia with a key to the Western Palaearctic Xylophrurus species (Hymenoptera: Ichneumonidae). Folia entomologica hungarica, 76: 223-240. doi: 10.17112/FoliaEntHung.2015.76.223

VAS, Z. (2016a): Woldstedtius merkli sp. n. from Hungary (Hymenoptera: Ichneumonidae). Folia entomologica hungarica, 77: 57-65. doi: 10.17112/FoliaEntHung.2016.77.57

VAS, Z. (2016b): New records of wasps in Hungary and Romania (Hymenoptera: Ichneumonidae, Ves- pidae). Folia entomologica hungarica, 77: 67-78. doi: 10.17112/FoliaEntHung.2016.77.67

VAS, Z. (2016c): Contributions to the knowledge of Ichneumonidae and Gasteruptiidae fauna of Sălaj County, Romania (Hymenoptera). Studia Universitatis "Vasile Goldiş", Seria Ştiințele Vieții, 26(1): 133-140.

VAS, Z. (2016d): A new species of Temelucha Förster from Malta with an updated and revised identification key to the Western Palaearctic Temelucha species (Hymenoptera, Ichneumonidae, Cremastinae). Journal of Hymenoptera Research, 48: 6784. doi: $10.3897 /$ JHR.48.7094

VAS, Z. (2016e): Temelucha flavia sp. n. from the southern Mediterranean region (Hymenoptera: Ichneumonidae: Cremastinae). Ecologica Montenegrina, 8: 38-44.

VAS, Z. (2018): New species and new records of ichneumon wasps from Hungary and adjacent countries (Hymenoptera: Ichneumonidae). Folia entomologica hungarica, 79: 81-100. doi: 10.17112/FoliaEntHung.2018.79.81

VAS, Z. (2019a): Contributions to the taxonomy, identification, and biogeography of the Western Palaearctic species of Campoletis Förster (Ichneumonidae: Campopleginae). Zootaxa, 4565(3): 373-382. doi: 10.11646/zootaxa.4565.3.4

VAS, Z. (2019b): New species and new records of ichneumon wasps from the Eastern Mediterranean and the Black Sea regions (Hymenoptera: Ichneumonidae). Acta Zoologica Academiae Scientiarum Hungaricae, 65(1): 19-30. doi: $10.17109 /$ AZH.65.1.19.2019

VAS, Z. (2019c): Contributions to the taxonomy, identification, and biogeography of Eriborus Förster, 1869 and Nepiesta Förster, 1869 (Hymenoptera: Ichneumonidae: Campopleginae). Opuscula Zoologica Budapest, 50(1): 87-98. doi: $\underline{10.18348 / \text { opzool.2019.1.87 }}$

VAS, Z. (2019d): Contributions to the taxonomy, identification, and biogeography of Casinaria Holmgren and Venturia Schrottky (Hymenoptera: Ichneumonidae: Campopleginae). Zootaxa, 4664 (3): 351-364. doi: 10.11646/zootaxa.4664.3.3

VAS, Z. (2019e): New species and new records of Campopleginae from the Palaearctic region (Hymenoptera: Ichneumonidae). Folia entomologica hungarica, 80: in press 
VAS, Z., Mifsud, D. \& BROAD, G.R. (2015): New records of ichneumon wasps (Hymenoptera: Ichneumonidae) from Malta. Bulletin of the Entomological Society of Malta, 7: 139-142.

VIERECK, H.L. (1914): Type species of the genera of Ichneumon flies. United States National Museum Bulletin, 83: 1-186. doi: 10.5479/si.03629236.83.1

XU, G.T. \& SHENG, M.L. (1994): (A new species of the genus Lathrostizus (Hymenoptera: Ichneumonidae:
Porizontinae). Scientia Silvae Sinicae, 30(4): 332333.

YU, D.S. \& HoRstMANN, K. (1997): A catalogue of world Ichneumonidae (Hymenoptera). The American Entomological Institute, Gainesville, pp. 1558.

Yu, D.S., AchterberG, C. VAn \& Horstmann, K. (2012): Taxapad 2012, Ichneumonoidea 2011. Database on flash-drive. www.taxapad.com, Ottawa, Ontario. 